\title{
High-resolution crystal structure of the Fv of quaternary neutralizing epitope mAb 2909 reveals atomic details of its antigen-binding site
}

\author{
JM Sampson*, A Killikelly, H Zhang, MK Gorny, S Zolla-Pazner, X Kong \\ From AIDS Vaccine 2012 \\ Boston, MA, USA. 9-12 September 2012
}

\section{Background}

Human mAb 2909 is in a class of potently neutralizing mAbs against the HIV-1 quaternary neutralizing epitope (QNE) preferentially presented by the native Env trimer complex. Its distinctive feature is a long CDR H3 loop with 2 sulfated tyrosines that are suggested to play a key role in antigen binding. Two structures of the Fab fragment of 2909 have been published, but at only $3.3 \AA$ and $3.2 \AA$ resolution, respectively, some atomic-level details of the antigen binding sites of these structures are contradictory.

\section{Methods}

After crystallizing a recombinant $\mathrm{Fv}(\mathrm{rFv})$ of mAb 2909, expressed as a single chain in E. coli and refolded from inclusion bodies, we solved and refined its structure to $1.9 \AA$ resolution. We also characterized the neutralizing activity of the rFv against pseudotyped virus SF162.

\section{Results}

Despite lacking the native sulfation of 2 tyrosine residues at the apex of CDR H3, rFv 2909 retains neutralization activity against SF162 pseudoviruses. Our high-resolution structure features a series of 5 tyrosine residues decorating one face of $\mathrm{H} 3$ like rungs of a spiral staircase, as seen in the Spurrier structure. The presence of this feature, despite different crystal packing around the H3 loop, suggests that the stacking pattern is not an artifact of crystallization, and that these tyrosine side chains play an important role in epitope recognition.

\section{Conclusion}

Our structure of $\mathrm{rFv} 2909$ at $1.9 \AA$ resolution reveals additional atomic-level details of its antigen-binding site,

NYU School of Medicine, New York, NY, USA allowing further analysis of its binding mode. Our data demonstrate that $\mathrm{rFv}$ can be used as a tool to obtain high-resolution structures of antigen-binding regions, and may be useful for experiments requiring molecular weights smaller than that of a full Fab fragment, such as ITC and NMR spectroscopy.

Published: 13 September 2012

doi:10.1186/1742-4690-9-S2-P79

Cite this article as: Sampson et al:: High-resolution crystal structure of the Fv of quaternary neutralizing epitope mAb 2909 reveals atomic details of its antigen-binding site. Retrovirology 2012 9(Suppl 2):P79.

Submit your next manuscript to BioMed Central and take full advantage of:

- Convenient online submission

- Thorough peer review

- No space constraints or color figure charges

- Immediate publication on acceptance

- Inclusion in PubMed, CAS, Scopus and Google Scholar

- Research which is freely available for redistribution

\section{Biomed Central}

( 2012 Sampson et al; licensee BioMed Central Ltd. This is an Open Access article distributed under the terms of the Creative Commons Attribution License (http://creativecommons.org/licenses/by/2.0), which permits unrestricted use, distribution, and reproduction in any medium, provided the original work is properly cited. 